\title{
Editorial Foreword 71.2 (May 2012)
}

\section{Our Cover}

This photo was taken by Angilee Shah in May 2008 from a bridge overlooking the Sai River, which sits between Thailand and Myanmar. On the right are bustling tourist and trinket shops in the Thai city of Mae Sai. On the left are hollowed out buildings of the Myanmar city of Tachilek. You can cross the border from Thailand into Myanmar by foot by paying US\$10 or 500 Thai Baht and leaving your passport with Myanmar officials until you re-enter Thailand. Photo used here with permission.

\section{An Overview of The Issue:}

As in recent years, events taking place in Asia frequently made global headlines in 2011. One of the year's biggest stories relating to Northeast Asia came in the opening months of 2011. It began with Japan being rocked by an earthquake and hit by a tsunami, a pair of intertwined disasters that not only led to a significant initial loss of life but quickly triggered concerns over the danger of radiation pouring out of a nuclear power plant. One of the year's biggest stories relating to Southeast Asia, by contrast, came toward the end of 2011 and involved an unexpected, and, to the minds of many, hopeful political development: the release from house arrest of the best known Burmese democracy activist. I am pleased that, due in part to planning and in part to happenstance, this issue of the JAS offers both an early effort to place the Japanese disaster into historical perspective and two essays that, between them, may be helpful for those interested in trying to figure out where events in Myanmar may be leading. After starting with a series of pieces that deal with those two contemporary settings, the issue continues with contributions that move to other parts of Asia, to other periods in time, or both. The contributors are, as has become the norm, based in widely varied disciplines (among them anthropology, history, ethnomusicology, and political science) and disparate parts of the world (the United States, Japan, Thailand, South Korea, and Singapore).

\section{Asia Beyond the Headlines}

We begin with a symposium on Japan one year after the crisis. It opens with an introductory essay, "Living With Uncertainty: After March 11, 2011," by 
Associate Editor JoRDAn SAND, a specialist in Japanese history who played a crucial role in commissioning and editing the section. Completing the symposium are: Yoshimi SHun’YA’s "Radioactive Rain and the American Umbrella," an elegant exploration of a wide range of issues, which was translated by SHI-LIN $\mathrm{LOH}$ (who also compiled a set of readings to complement the arguments in the piece); Greg Clancey’s "Japanese Seismicity and the Limits of Prediction," which offers a fascinating window on the way earthquakes are thought about and studied in Japan; and Alexis DudDen's “The Ongoing Disaster," which draws upon both the author's experiences in Japan in March 2011 and research on Japan in wartime. This "Asia Beyond the Headlines" feature is meant to complement discussions of the Japanese disaster that have been going on among scholars of Asia since the weeks immediately following the tsunami. This is not the place to give a list of those discussions, but three things are worth noting here. First, one of the most talked about panels at the 2011 Association for Asian Studies annual meeting was one devoted to the subject that was put together at the last minute by historian William M. Tsutsui and others. Second, one of the best online-only publications devoted to Asia, The AsiaPacific Journal: Japan Focus, has published a host of timely commentaries on the topic. Third, in addition to playing a crucial role in this symposium, Jordan Sand contributed a piece to the London Review of Books ("Diary," April 28, 2011, pp. 34-35) that was among the most illuminating early reflections on the crisis.

\section{Two Essays on Myanmar}

Unlike the symposium on Japan, which was put together self-consciously as a set, the pair of pieces devoted to Myanmar ended up in the same issue as the result of a fortuitous convergence of developments. Some time ago, we asked JACQUES P. LEIDER to write about several recent books on the politics of the country. Meanwhile, Elliott Prasse-Freeman submitted an essay to us based on his time spent doing research there. We are very pleased to be able to publish them together here, the first as "Trends" essay entitled "Domination and Dereliction: Exploring the State's Role in Burma," the second as "Power, Civil Society, and an Inchoate Politics of the Daily in Burma/Myanmar." And also note that both can be usefully read in conjunction with the "Asia Beyond the Headlines" piece that ran in these pages last year.

\section{Research Articles on the Himalayas and the Korean Peninsula}

Another unplanned feature of this issue is that the final four research articles can be seen as a pair of essays on Korea bookending two very different studies of a Himalayan setting. In the first of these four, "Moral Imperatives: South Korean Studenthood and April 19 ${ }^{\text {th }}$, historian CharLes R. Kim explores the large-scale demonstrations of 1960_important events that he claims have too often 
overlooked in discussions of the "Global Sixties" that emphasize the importance of campus activism in that dramatic decade. Following that comes anthropologist Chris VasantKumar's sophisticated look at the complex working of identity categories, "What Is This 'Chinese' in Overseas Chinese?: Sojourn Work and the Place of China's Minority Nationalities in Extraterritorial Chinese-ness," which is based on fieldwork in a multiethnic part of Gansu Province at the northeast edge of the Qinghai-Tibet plateau. Next comes ethnomusicologist STEFAn Fiol's "Articulating Regionalism through Popular Music: The Case of Nauchami Narayana in the Uttarakhand Himalayas," a nuanced study of a protest anthem that, despite efforts by the local government censors to stem its dissemination, the author claims became "the best-selling song in the history of Garhwali language popular music." The issue ends with historian JaE-Hoon Shim's "An Ever-Contested Poem: The Classic of Poetry's 'Hanyi' and the Sino-Korean History Debate," which offers an insightful untangling of the ongoing and still politically charged debate on whether the state referred to in an ancient verse should be seen as describing a "Chinese" or "Korean" locale.

\section{Forthcoming Articles in JAS 71:3 (August 2012)}

Asia Beyond the Headlines

Anna Hazare and the Idea of Gandhi

Mitu Sengupta

Research Articles

Modular History: Identity Maintenance before Uygar Nationalism

Rian Thum

Constructing Myth in Modern China

Robin McNeAL

Lao Buddhist Monks and their Involvement in Political and Military Resistance to the Lao People's Democratic Republic Government Since 1975

IAN G. BAIRD

Profit and Protection: Emin Khwaja and the Qing Conquest of Central Asia, 1759-1777

KWANGMin Kim 


\section{Editorial Foreword}

Constructing Commonality: Standardization and Modernization in Chinese Nation-Building

ANDREW KIPNIS

Food Safety and Social Risk in Contemporary China YUNXIANG YAN 